(RESEARCH ARTICLE)

\title{
Lectin characterization of the gastrointestinal tract of three Nigerian passerine birds
}

\author{
Yetunde Olufunmilayo Ogunkoya * \\ Department of Biological Sciences and Chemistry, Southern University and A \& M College, Baton Rouge LA 70813 USA.
}

Publication history: Received on 19 August 2020; revised on 29 August 2020; accepted on 30 August 2020

Article DOI: https://doi.org/10.30574/wjarr.2020.7.2.0313

\begin{abstract}
The avian gastrointestinal tract was characterized using lectin cytochemistry Concanavalia agglutinin (Con A) and Arachis hypogea agglutinin, Peanut agglutinin (PNA). The apical cell boundaries of surface epithelial cells of both the proventriculus and ventriculus, the duct and glandular neck cells of the proventriculus, the intestinal brush borders, the surface epithelial cells of the sheep abomasum and the chief cells of the sheep abomasum were stained by Con A and PNA. The intracytoplasmic granules of the duct and glandular neck cells of the proventriculus, those of the chief or principal cells of the ventriculus, those of the goblet cells of the ileum, colon and cloaca and those of the chief and surface epithelial cells of the sheep abomasum were stained by PNA. Gastro-intestinal endocrine cells and the parietal cells of both the avian gut and the sheep abomasum were not stained by either lectins. The cytochemical results indicated that those cells stained by the two lectins have both $\alpha$-D- mannose or $\alpha$-D-glucose and $\beta$-galactose$(1,3)-\mathrm{N}$-acetyl-galactosamine residues in their membranes. Those stained by either of the two lectins had either of the two sugars as components of their cell membrane and their granules. Goblet cells were heterologous. The duct and glandular neck cells of the proventriculus, the chief cells of the ventriculus, the goblet cells of the ileum, colon, cloaca, and the chief and surface epithelial cells of the sheep abomasum had similar intracytoplasmic granules.
\end{abstract}

Keywords: Lectin; Cytochemistry; Gastrointestinal tract; Passerine; Bird

\section{Introduction}

The cell membrane, the gate keeper of cells is known to contain complex carbohydrates acting as receptors for biologically active reagents such as lectins. Lectins are oligomeric proteins or glycoproteins with two or more sugarbinding sites per molecule, capable of specific recognition and reversible binding to carbohydrate moieties of complex carbohydrates without altering the covalent structure of any of the recognised glycosyl ligands, [1,2,3], sugar-binding proteins of non-immune origin competent in agglutinating or precipitating cells with saccharides and are used in a variety of assays for the detection of specific oligosaccharides on cell surfaces $[3,4,5,6]$.

The conjugation of lectin with various markers: electron dense substances, beads, enzymes and fluorescein dyes has been used to label and characterize lectin receptors in normal and pathologic conditions of several mammalian tissues $[7,8]$. It is now known that the differences in carbohydrate profile reported in different parts and locations of the gastrointestinal tract is due to various reactions observed from different lectins and the interaction between a lectin and the cell membrane depends on carbohydrate moiety present in the membrane $[9,10]$. Since lectins are specific for a particular sugar, lectin binding has been used as a tool to provide insight into the biochemical composition of membranes [11,12], and to identify cell types in cytochemical studies in both tissue slices and cultured cells [1, 2, 8].

In intestinal tissue, lectins have been shown to interact with enterocytes, brush borders and goblet cells. For example, Con A (concanavalia agglutinin) interacts via $\alpha$-D-mannose and $\alpha$-D glucose while Arachis hypogea agglutinin, Peanut agglutinin, PNA interacts via disaccharide $\beta$-galactose- (1,3)-N-acetyl-galactosamine [5, 9, 11]. Falk et al. [12] reported

\footnotetext{
${ }^{*}$ Corresponding author Yetunde Olufunmilayo: Ogunkoya
} 
that there are no specific lectins for the gastric endocrine cells. However subsets of endocrine cells (ECs) react with PNA, TKA,

AAA, Lotus and UEA1 in the mouse gut [12]. Studies on ECs are difficult due to the fact that these cells are dispersed throughout the intestinal mucosa and cannot be readily isolated for culturing and specific studies. The fact that some ECs are stained by lectins led to the hypothesis that it might be possible to isolate and purify ECs using affinity chromatography and different lectins. The first part of the study was to establish whether or not ECs in the gastrointestinal tract could be stained with labelled lectins despite the fact that there is little or no evidence in the literature of lectins having been used to characterize or label the avian gastrointestinal tract or the sheep abomasum.

The overall aim of the study was to characterize the avian gut endocrine cells to provide base line information on the different segments of the avian gut and to compare lectin receptor sites of the avian gut with those of the sheep abomasum. Sheep abomasum was chosen for comparison with the avian gastrointestinal tract, since this tissue is larger and more readily obtainable than the gastrointestinal tracts of the species of birds under study. Furthermore, the presence of endocrine cells has been well established in the sheep. The lectins used were Con A and PNA. Con A (Concanavalia agglutinin) is specific for $\alpha$-D- mannose and $\alpha$-D-glucose and PNA (Arachis hypogea agglutinin, Peanut agglutinin) is specific for the disaccharide $\beta$-galactose- $(1,3)-\mathrm{N}$-acetyl-galactosamine.

\section{Material and methods}

\subsection{Sample collection and preparation}

Birds were trapped with mist nets under approval from Ministry of Agriculture and Natural Resources, Kaduna State, Nigeria, with the license issued by the Western Australian Department of Conservation and Land Management and with the approval of The Animal Experimentation Ethics Committee of Murdoch University. Captured birds weighed (9 - 13 g) anaesthetised and killed with intraperitoneal or oral barbiturate (sodium pentobarbitone (Sagatal, $60 \mathrm{mg} / \mathrm{ml}$. May and Baker Pty Ltd. Australia). Palpebral and muscle reflexes in both wings and legs were used to confirm surgical killing. The birds were perfused with half strength Karnovsky fixative (1.5\% glutaraldehyde, $0.8 \%$ paraformaldehyde in $0.1 \mathrm{~m}$ phosphate buffer, $\mathrm{pH}$ 7.3) via the left ventricle of the heart. Following in situ perfusion, the gastrointestinal tract was dissected free of its mesenteric attachments and the gastrointestinal tract was separated into its various segments of, proventriculus, ventriculus, duodenum, jejunum, ileum, ceca, colon and cloaca The specimens were measured and immersed either in the same fixative for $24 \mathrm{~h}$ for electron microscopy or in $10 \%$ neutral-buffered formalin for $24 \mathrm{~h}$ for light microscopy. Transverse sections of the proventriculus, gizzard, duodenum, jejunum, ileum, and rectum were processed for either routine light microscopy or routine transmission electron microscopy [13, 14]. Briefly, specimens for light microscopic study were dehydrated through graded alcohol and embedded in paraffin wax. TEM specimens were osmicated for different period of time $\left(90,60,3015,10\right.$ minutes respectively at $\left.4{ }^{\circ} \mathrm{C}\right)$. When pre- and post-treated samples did not observe lectin staining, specimens were finally processed without osmication.

For comparison, abomasal sections from sheep were prepared by washing the digesta from the surface with half strength Karnovsky fixative. $1 \mathrm{~mm}^{3}$ slices of abomasum were then fixed in half strength Karnovsky fixative for 24 hours and processed for EM without osmication. Specimens were processed for lectin binding.

\subsection{Dewaxing of paraffin sections and removing resin from plastic sections}

5-7 micron thick paraffin sections from each segment were floated on poly-L-Lysine coated glass slides and allowed to dry in the oven for 30 mins. Sections were deparaffinized in two changes of xylene over a 10 minute period and rehydrated through descending grades of alcohol to water.

$1 \mu$, semi-thin plastic sections were floated on poly-L-Lysine coated glass slides and allowed to dry overnight at $37{ }^{\circ} \mathrm{C}$. Plastic sections were treated with saturated potassium hydroxide in absolute ethanol for 15 minutes [15] and washed through three changes of absolute alcohol over a 10 minute period and in tris buffer for five minutes.

\subsection{Lectin binding}

Biotin conjugated Con A and PNA lectins (Sigma Aldrich, Pty. Ltd. Australia) were used for lectin binding and detection.

All the samples of de-waxed and de-plasticized sections were treated with $0.3 \%$ hydrogen peroxide $\left(\mathrm{H}_{2} \mathrm{O}_{2}\right)$ for 30 minutes to inhibit the endogenous peroxidase reaction $[16,17]$. Tissues were rinsed in tris buffer for 30 minutes and were then incubated in a biotin-labelled lectin (Con A; PNA,) diluted at a concentration of 1:10 in tris buffer overnight 
at $4{ }^{\circ} \mathrm{C}$ in a moist chamber. Tissues were washed in six changes of tris buffer over a thirty minute period, after which they were incubated at room temperature in streptavidin peroxidase conjugate diluted at a concentration of 1:50 for one hour in a moist chamber. Tissues were washed in six changes of tris buffer over thirty minute period and were then stained with freshly prepared and filtered $5 \mathrm{mg}$ of 3,-31 diaminobenzidine tetrahydrochloride $(5 \mathrm{mg} / 10 \mathrm{ml} \mathrm{DAB})$ in 10 $\mathrm{ml}$ of tris buffer (activated just prior to use with $0.003 \%$ hydrogen peroxide) for thirty minutes to detect lectin reaction and finally rinsed in six changes of tris buffer $[5,12]$.

\subsection{Staining}

Paraffin sections were stained lightly in Harris's Haematoxylin and plastic sections were stained lightly in toluidine blue and mounted in cover slips. Sections were examined with an Olympus BH2 light microscope.

\section{Results}

The two lectins employed in the present study did not recognise the endocrine cells of neither the avian gastrointestinal tract nor the sheep abomasum No staining was observed on pretreated and osmicated tissues or postfixed and treated tissues with labelled lectin.

The results below are based on deparaffinized and non-osmicated, deplasticized sections. The staining observed on paraffin sections was comparable to that seen on plastic sections with some variations. However, the plastic sections appeared to show the reaction more clearly. The two lectins used in this study labelled the connective tissue cells, endothelial cells, myocytes, myelin and red blood cells in both the avian gastrointestinal tract and the abomasum of sheep. The staining reaction in paraffin embedded tissues ranged from light to dark brown or no colouration while in the plastic sections the reaction produced was black or colourless (Figs. 1a and b). Although Con A and PNA labelled the cells of these segments with the same intensity, there were some differences in the staining reaction of these two lectins (Table 1).

\subsection{Con A binding on the avian gut}

Con A labelled all the cells and tissues of the gut in these species and labelling intensity on all segments ranged from very weak to dark brown colour. The apical or luminal cell boundaries of the proventriculus were stained dark brown. There was selective staining of the chief, parietal- like cells of the proventriculus. The glandular neck cells, duct and surface epithelial cells were also recognized. The connective tissue, muscle and the serosa were all stained brown (Fig. 1).

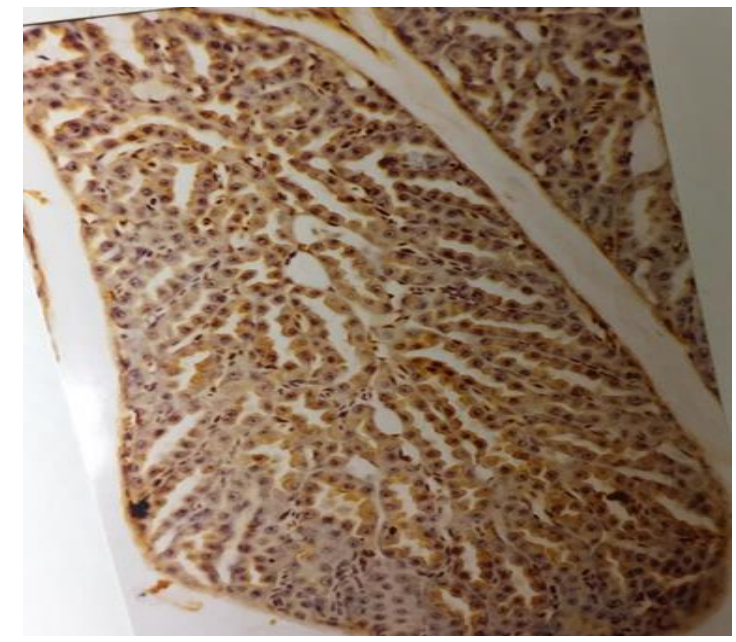

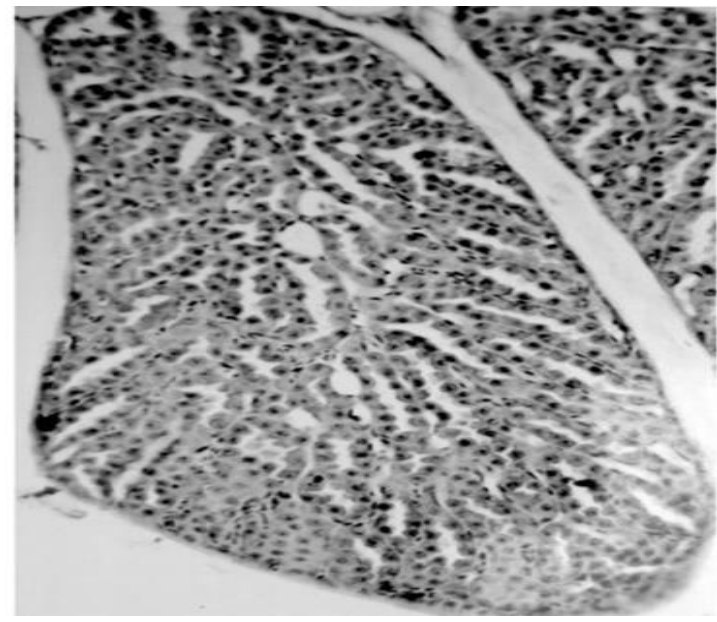

$\mathrm{b}$

Figure 1 a and b Light micrographs showing $5 \mu \mathrm{m}$ thick sections of the proventriculus stained with Con A. Note the brown colouring of the chromogen, especially associated with the chief cells away from the basal region of the glands $\mathrm{X} 280$.

The staining intensity of Con A on cells of the ventriculus is comparable to that of the proventriculus. There was dark brown staining of the luminal cell boundaries of the surface epithelial cells. The surface cuticle (koilin membrane), apical 
cell boundaries of chief cells of the ventricular glands and the foamy koilin membrane at the base of some glandular units were stained light brown. Muscle, connective tissue and the serosa took the brown colour of the chromogen.

The brush border of the intestinal tract stained dark brown. Other layers of the intestinal tract had the brown stain of the chromogen.

Con A binding on deplasticized $1 \mu \mathrm{m}$ semi-thin sections of the proventriculus showed epithelial cells with a staining intensity ranging from no colouration to black. The membrane of cells of the other layers of the proventriculus were stained black. Con A only stained the apical and lateral cell boundaries of the glandular neck cells, duct cells and the surface epithelial cells. There was light to weak staining of the apical and lateral cell regions of the parietal-like cells of the proventriculi (Fig. 2).

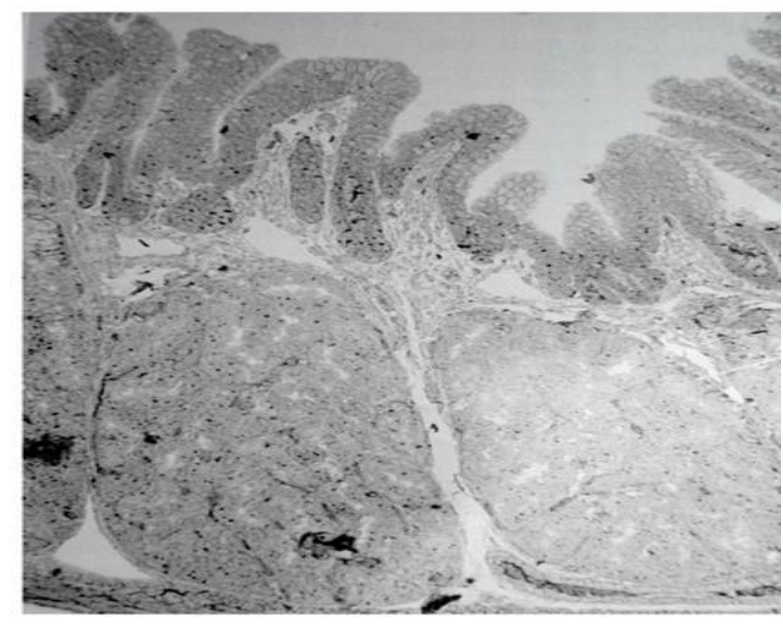

Figure 2 Light micrograph showing the staining due to Con A on a $1 \mu \mathrm{m}$ semithin section of the proventriculus. The reaction product highlights the cell boundaries of stained cells x180.

\subsubsection{Ventriculus}

There was light staining of the luminal cell membranes of the surface epithelial cells of the ventriculi. Chief cells and the cuticle (koilin membrane) were not stained by Con A. The connective tissue, myocytes and the serosa were stained light black.

\subsubsection{Intestine}

The intestines stained black at the brush border. The lateral regions of cells were stained light black. The enterocytes and the goblet cells had their apices and their lateral cell boundaries lightly recognised by Con A.

\subsubsection{PNA binding on the avian gut}

The reaction of PNA on $5 \mu \mathrm{m}$ dewaxed thick sections was similar to that of Con A on proventriculus. There was dark brown colouration of the surface epithelial cells, the majority of the chief, parietal-like cells, glandular neck cells, duct cells and all the other tissues (Fig 3). The intracytoplasmic granules of both duct and the glandular neck cells were also recognised. 


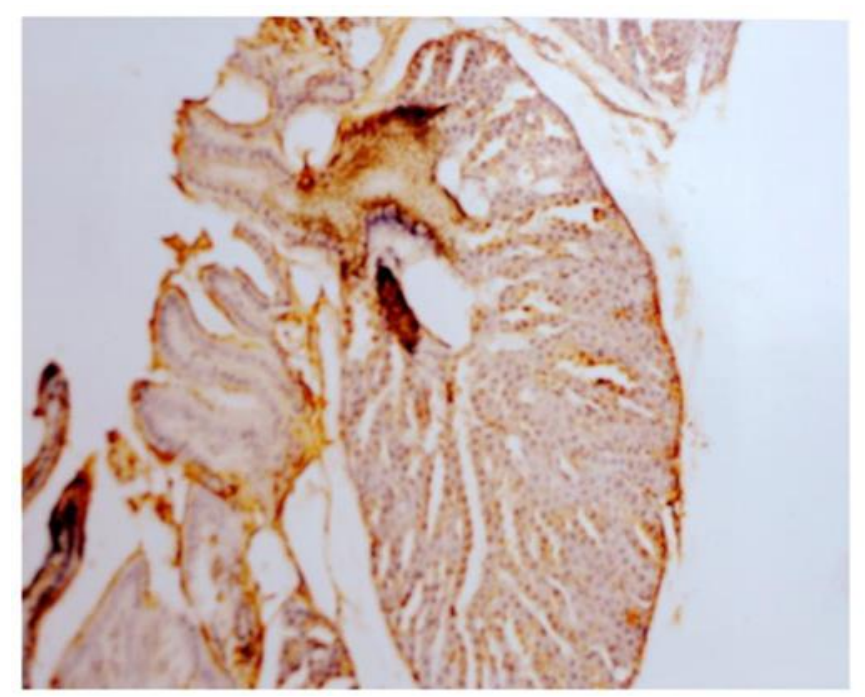

Figure $3 \mathrm{LM}$ of PNA staining on a $5 \mu \mathrm{m}$ thick section of the proventriculus Note the dark brown staining of the glandular neck cells x180

PNA stained tubular cuticle (koilin membrane) of the ventriculus golden brown and portions of tubular koilin membrane in the luminal cuticle. The luminal cell boundaries of the chief cells were stained golden to dark brown.

The intestinal brush border was stained dark brown by PNA. The luminal borders of the enterocytes were weakly stained. In the large intestine, the intracytoplasmic contents of the goblet cells were stained.

On $1 \mu \mathrm{m}$, deplasticised, semithin sections of the proventriculus, PNA stained both the glandular neck and the duct cells with their intracytoplasmic granules (Fig 4). Most cells of the proventricular surface epithelium had little to no staining.

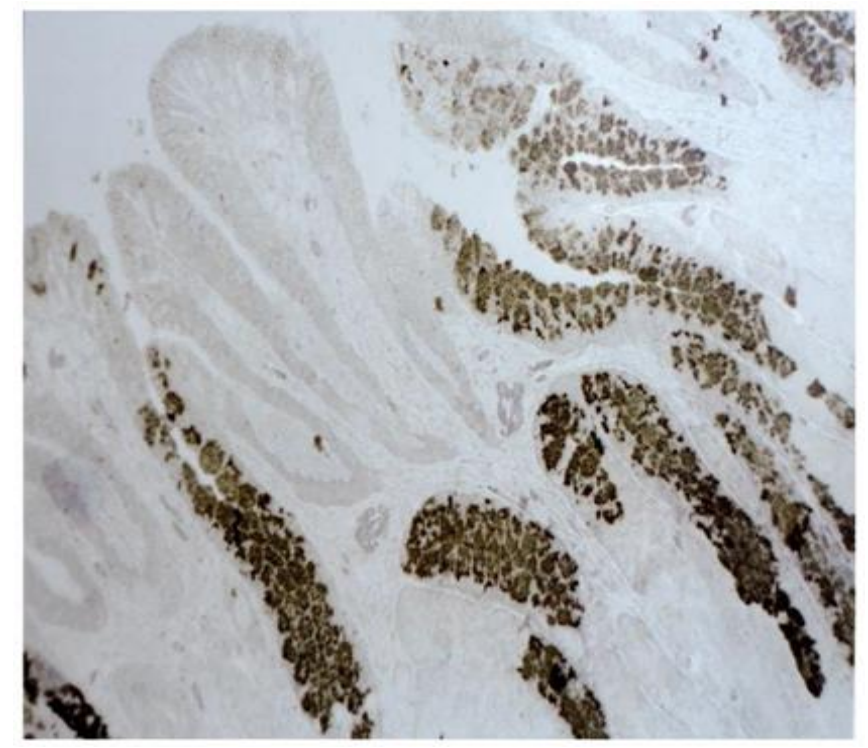

Figure 4 LM of PNA staining on $1 \mu \mathrm{m}$ semithin section of the proventriculus. Reaction product shows the cell boundaries and the intracytoplamic granules of glandular neck cells and duct cells of the proventriculus x280.

PNA stained the surface epithelial cells of the ventriculus. It selectively stained the tubular koilin membrane, the apical or luminal surfaces of chief cells and their intracytoplamic granules.

The enterocytes were recognised by PNA. The brush border and the luminal aspect of the enterocytes were strongly stained by PNA. The staining was weak on the basolateral aspect of these cells. The reaction in both the duodenum and the jejunum were similar. In the ileum PNA not only stained the brush borders and luminal aspects 
of cells, it also recognised the intracytoplasmic granules of the goblet cells and the basolateral aspect of these cells (fig. 5), all of which was stained heavily. Some intracytoplasmic granules of the goblet cells were stained in both the colon and cloaca.

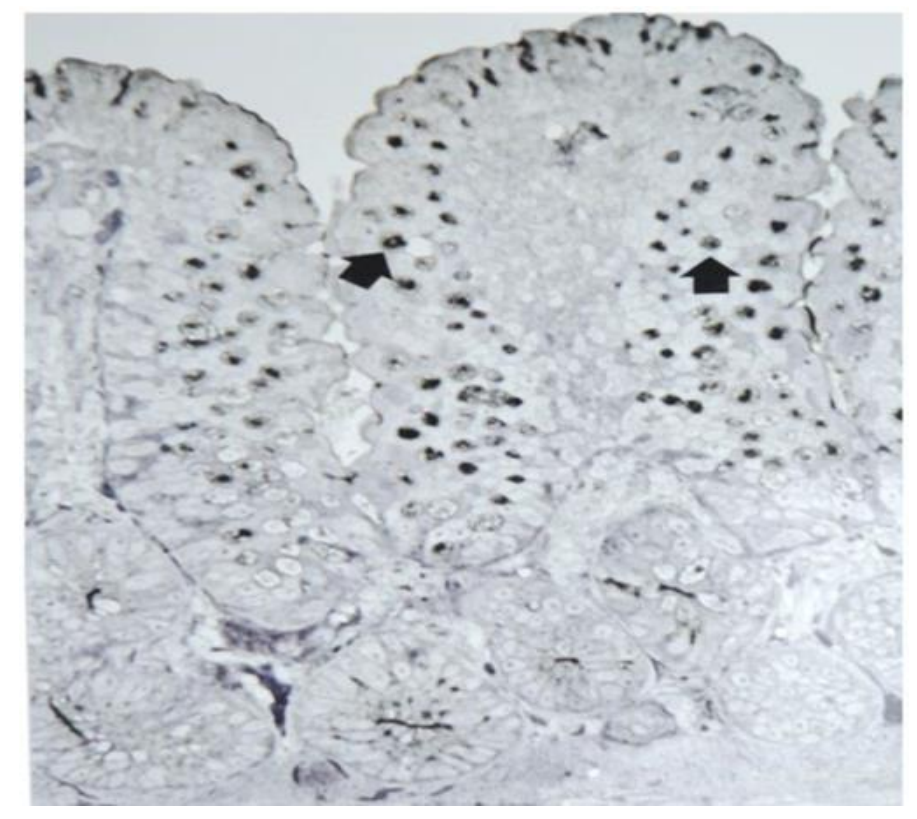

Figure 5 Light micrograph of PNA staining on the colon. Note the reaction product associated with intracytoplasmic granules of the goblet cells (arrow) X280

\subsubsection{Sheep abomasum}

PNA stained the apical and basolateral boundaries of the surface epithelial cells as well as their intracytoplasmic granules. It equally recognised the luminal cell boundaries of the chief cells as well as their intracytoplasmic granules. However, PNA did not stain the parietal cells of the sheep abomasum (Fig. 6).

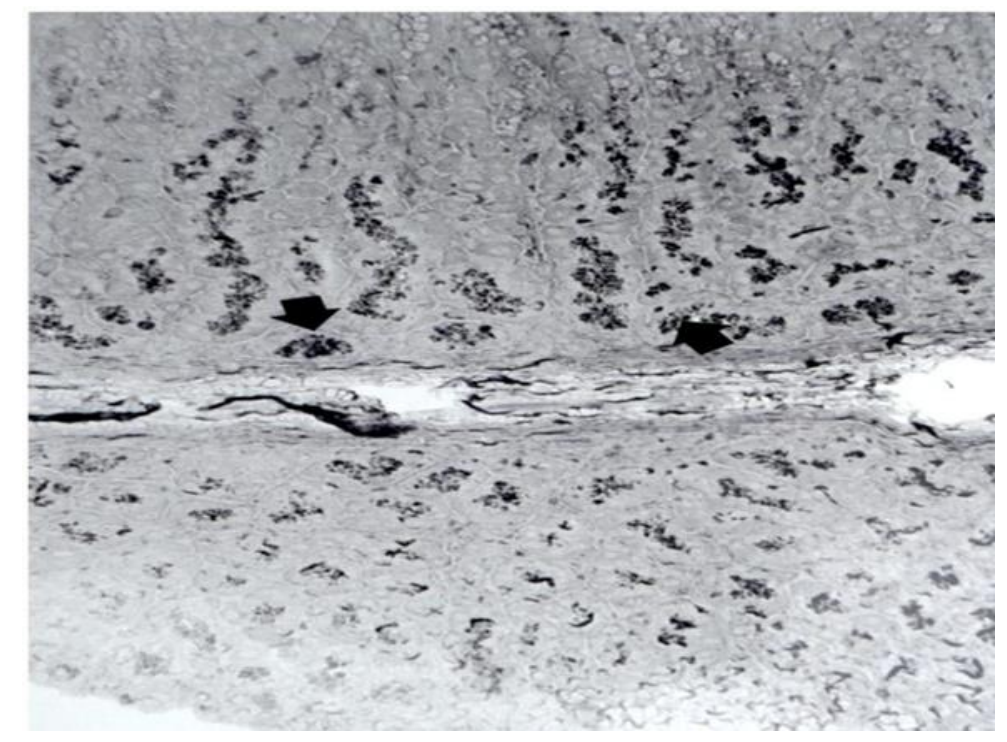

Figure 6 Light micrograph of a portion of sheep abomasum stained with PNA. .Note the reaction product is especially associated with the intracytoplasmic granules of the chief cells. X170. 
Table 1 Lectin binding intensity with the cells of various segments of the gut

\begin{tabular}{|c|c|c|c|c|}
\hline & \multicolumn{2}{|c|}{$5 \mu \mathrm{m}$ sections } & \multicolumn{2}{|c|}{$1 \mu \mathrm{m}$ sections } \\
\hline & CON A & PNA & CON A & PNA \\
\hline \multicolumn{5}{|l|}{ Proventriculus } \\
\hline SEP luminal membrane & +++ & +++ & ++ & +++ \\
\hline SEP lateral membrane & +++ & +++ & ++ & +++ \\
\hline Chief (oxyntic/parietal) cell & \pm & +++ & \pm & - \\
\hline Duct cell, apical and lateral membranes & +++ & +++ & + & +++ \\
\hline Granules of duct cells & - & +++ & - & +++ \\
\hline Glandular Neck cell & ++ & +++ & + & +++ \\
\hline Granules of glandular neck cells & - & +++ & - & +++ \\
\hline All other cells and tissues & + & + & & + \\
\hline \multicolumn{5}{|l|}{ Ventriculus } \\
\hline SEP luminal membrane & +++ & + & + & +++ \\
\hline Tubular cuticle & - & ++ & - & ++ \\
\hline Luminal cuticle & & + & - & ++ \\
\hline Apical membrane of chief cells & + & +++ & - & ++ \\
\hline Granules of ventricular chief cells & - & - & - & ++ \\
\hline All other cells and tissues stained light brown & + & & + & + \\
\hline \multicolumn{5}{|l|}{ Intestine } \\
\hline Brush border & +++ & +++ & +++ & +++ \\
\hline Enterocytes & + & + & + & +++ \\
\hline Goblet cells & + & ++ & + & +++ \\
\hline Granules of goblet cells in the large intestine & - & +++ & + & +++ \\
\hline \multicolumn{5}{|l|}{ Sheep abomasum } \\
\hline SEP luminal membrane & +++ & +++ & +++ & +++ \\
\hline SEP basolateral membrane & +++ & +++ & +++ & +++ \\
\hline Chief cells (zymogen cells & +++ & +++ & +++ & +++ \\
\hline Granules of chief cells & & +++ & - & +++ \\
\hline Parietal cells & - & - & - & - \\
\hline
\end{tabular}

\section{Discussion}

It is surprising to observe that the results on the $5 \mu \mathrm{m}$ deparaffinised, thick sections was not consistent with those of the $1 \mu \mathrm{m}$ deplasticised semithin sections. In the paraffin sections, the two lectins strongly stained the apical cell boundaries of the chief and parietal cells whereas on $1 \mu \mathrm{m}$ plastic sections, there was weak to no staining of these cells by both lectins. This discrepancy in the two results may be due to differences in the thickness of the sections and/or that the chromogen was not completely washed off from the paraffin thick sections.

The expected colouration from the treatments should have been the colour of the chromogen, brown colouring. Black colouration was observed in the semithin plastic sections instead of brown colouration. The unexpected black colour 
even on sections not stained with toluidine blue may be due to the fact that there might have been more antibodies (more hapten/specific sugars) at these sites for the colour to turn black. Other immunohistochemical studies have observed this type of colouration on semi-thin or thick sections $[4,18]$.

\subsection{Thickness of tissue sections used in the current study}

Both lectins stained 3-5 $\mu \mathrm{m}$ dewaxed/deparaffinised and $1 \mu \mathrm{m}$ deplasticised semithin sections at a dose rate of up to $100 \mu \mathrm{g} / \mathrm{ml}$. This observation has been reported by Coggi et al. [19] on $3 \mu \mathrm{m}$ dewaxed sections of gastrointestinal tract; by Viale et al. [15] on $1 \mu \mathrm{m}$ deplasticised semithin sections of gastric biopsy; by Ishizuya-Oka \& Shimozawa [17] on 4 $\mu \mathrm{m}$ dewaxed sections of digestive tract and by Falk et al. [12] on $5 \mu \mathrm{m}$ dewaxed sections of gut epithelia.

The current observations that the parietal cells did not react with the two lectins agree with those of Falk et al. [12]. Parietal cells of the proventriculus and the abomasum of sheep did not react with either of the two lectins used in this study. Fischer [20] reported on the contrary that both of these lectins recognized parietal cells of the normal human gastric mucosa. The difference in the reaction of these two lectins may be due to species difference. Gomez-Santos et al. [10] reported locational staining differences of parietal cells. PNA reacted heavily with the parietal cells in the upper region of the rat gastric gland and did not recognize the parietal cells in lower region of the same gland and Con A gave poor to no labelling on these cells.

The present observation on the glandular neck cells of the proventriculus, the chief cells of sheep abomasum and chief cells of the gizzard is similar to that of Falk et al. [12]. Their studies on the mouse stomach showed that both Con A and PNA reacted with the cell boundaries of the zymogen cells. In addition to labelling the cell boundary, PNA also labelled the zymogen granules of the chief cells of the sheep abomasum, granules of the avian glandular neck cells and duct cells of the proventriculus. This minor difference in reaction of the zymogen granules may be due to differences in species, different sampling regimen between the two studies and/or dietary differences. However, Ishizuya-Oka \& Shimozawa [17] observed similar reactions in the digestive tract epithelia of tadpole of South African clawed frog, Xenopus laevis.

It is known that chief cells of the mammalian stomach [21, 22] and the chief cells of the avian gizzard [23, 24] produce zymogen granules. The concurrent recognition of the membrane and the intracytoplasmic granules of the chief cells of the sheep abomasum, the duct and glandular neck cells of the proventriculus by the PNA suggests that the duct and glandular neck cells of the proventriculus are zymogen cells synthesizing and secreting zymogen Thus some of the granules in the duct and glandular neck cells of the proventriculus may be zymogen granules.

Both lectins reacted with the brush border of the enterocytes. This observation has been reported by Pang et al., [11] in gastrointestinal epithelia of rat, by Gelberg et al. [5] on porcine small intestine and by Falk et al. [12] on mouse gut epithelia. Furthermore, PNA stained intracytoplasmic granules of the goblet cells. The reaction in the different segments was intensely black and it recognised the basolateral boundaries of the enterocytes. The lack of affinity of Con A for the goblet cells in this study reinforces the reports of earlier workers $[4,5,25,26]$.

Insensitivity of the lectins to stain target cells might be due to any or some or all of the following reasons:

\subsection{Thickness of the tissue before processing}

In order to allow unlimited access of the lectin marker to intracellular structures, as well as cell surface components, lectin immunocytochemical studies have employed various tissue thicknesses $(30 \mu \mathrm{m}, 50 \mu \mathrm{m}, 60 \mu \mathrm{m}, 100 \mu \mathrm{m}$, less than $1 \mathrm{~mm}$ and $1 \mathrm{~mm}$ ) in the pre-embedding procedure [27, 28, 29, 30]. The current study made use of $1 \mathrm{~mm}$ initially and was subsequently adjusted to tissues of less than $1 \mathrm{~mm}$ thickness for pre-embedding. However, it was not possible to cut precise $60 \mu \mathrm{m}$ tissue sections without a vibratome. This problem was eliminated by sectioning only the peripheral areas of tissue blocks, as it is possible that the lectin might not have penetrated deeply into the tissue.

\subsection{Lectin conjugant and dosage}

Earlier immunocytochemical studies on the neuroepithelial bodies and gastrointestinal tissue employed ferritin or gold conjugated lectins $[12,18,31]$ as compared to biotin conjugated lectin used in this study. Thus lectin insensitivity in the current study might be due to the fact that ferritin is heavier and more electron-dense than biotin.

Ito et al., [31] in their immunocytochemical study on the bronchiolar neuroepithelial bodies, employed $100 \mathrm{mg} / \mathrm{ml}$ protein for pre-embedding as compared to $100-200 \mu \mathrm{g} / \mathrm{ml}$ protein used in the current examination. Thus the differences might be due to the difference in the dosages of lectin employed, as the current study could only afford one-thousandth of the earlier study and may as well be due to tissue difference. However, it is most probable that their dosage is a 
misprint since most other studies have utilised a much lower concentration which probably reflects the cost of the purified lectins.

Masking of reaction site by osmium tetroxide - Both osmium and lectin react with the cell membrane [2, 15]. Lectin insensitivity might be due to the masking of reaction site by osmium tetroxide [15, 32]. To overcome the problem posed by masking or oxidising with osmium, osmication was omitted, positive reactions were observed only in non-osmicated and deplasticised tissue sections.

\subsection{Lectin insensitivity}

The observation in the present species of birds supports the concept that there are no specific lectins for the gastrointestinal endocrine cells [11] since Con A and PNA show no specificity for the membranes of gut ECs. The observation in the current study disagrees with the claim that subsets of enteroendocrine cells react with PNA [11] since PNA failed to recognise the endocrine cells in the current species of birds as well as in the sheep. Lectin insensitivity to label target cells in the current study may be due to species differences and or that the enteroendocrine cells do not have $\beta$ galactose-(1,3)-N-acetyl-galactosamine in their cell membranes nor in their intracytoplasmic granules. The lectins used in the current study did not recognise the target cells (the endocrine cells in both the avian gastrointestinal tract and the abomasum of sheep) in 0.5-1 $\mu$ m deplasticised, semithin sections. However, these lectins recognised other cells and PNA even stained some intracytoplamic granules of some goblet cells. The lack of lectin staining of the gastro-intestinal endocrine cells meant that the ultimate aim of isolating these cells using affinity chromatography was not a viable proposition.

\section{Conclusion}

- $\quad$ Neither Con A nor PNA stained the parietal cells of the proventriculus indicating that the chief (parietal) cells in these species are mainly oxyntic cells and that they lack the specific sugars for either Con A or PNA.

- The staining by PNA of some of the intracytoplasmic granules of the duct and glandular neck cells of the proventriculus and those of goblet cells in the ileum, colon and cloaca of birds as well as the surface epithelial cells and chief cells of the sheep abomasum suggests a similarity between these granules irrespective of their location.

- The ability of PNA to recognise the zymogen cells of the sheep abomasum as well as the granules of the chief cells of the gizzard and the glandular neck cells of the proventriculus may indicate their similarity.

- The different staining reaction of the granules of the goblet cells in the different segments of the avian gut confirms their heterogeneity. This result indicates that these cells have either or both of those two sugars ( $\alpha$ D-mannose, $\alpha$-D-glucose residues and $\beta$-galactose-(1,3)-N-acetyl- galactosamine as components of their cell membrane while the intracytoplasmic granules recognised by only PNA have $\beta$-galactose- $(1,3)-\mathrm{N}$-acetylgalactosamine in their membranes.

\section{Compliance with ethical standards}

\section{Acknowledgments}

The author is thankful to Dr. Ogbajah J. for helping to obtain State licence from MANR, Kaduna State, Nigeria for sample collection, Professors Ezealor A, and Ogunkoya AB of Ahmadu Bello University for their assistance in obtaining the specimens, the Technologist, Mr. Fallon P of the Electron Microscopy Unit for his tutelage on EM usage, Professor Cook RD. 'my mentor' and Murdoch University and AID for financial support.

\section{Disclosure of conflict of interest}

There is no conflict of interest.

\section{Statement of ethical approval}

Ethical approval for this study was given by The Animal Experimentation Ethics Committee of Murdoch University, Murdoch, Western Australia 


\section{References}

[1] Manal T, May A, Quinn J, Lafontant DS, Shifatu O, Wei He JM, Gonzalez-Rosa JM, Burns GC, Burns CE, Burns AR, and Lafontant PJ. (2016). Differential lectin binding patterns identify distinct heart regions in giant Danio (Devario aequipinnatus) and Zebrafish (Danio rerio) hearts. Journal of Histochemistry \& Cytochemistry, 64(1), 687-714.

[2] Kocourek J and Horejsi V. (1982). A note on the recent discussion on definition of the term "Lectin". In: BøgHansen TC and Spengler GA. (Eds.), Lectins: Biology, Biochemistry, Clinical Biochemistry. Walter de Gruyter \& Co, Berlin, New York, 3, 3-6.

[3] Lis H and Sharon N. (1986). Lectins as molecules and as tools. Annual Review of Biochemistry, 55, 35-67.

[4] Castagnaro M and Canese. (1990). Lectin histochemical characteristics of the canine female mammary gland. American Journal of Veterinary Research, 51, 1815-1819.

[5] Gelberg H, Whiteley RG, Ballard HG, Scott J and Kuhlenschmidt M. (1992). Temporal lectin histochemical characterization of porcine small intestine. American Journal of Veterinary Research, 53, 1873-1880.

[6] Lee YC, Liu HC, Chuang C and Lin SH. (2015). Lectin magnetic beads for plasma membrane isolation. Cold Spring Harb, Protoc, 67, 4-8.

[7] Damjanov I. (1987). Lectin histochemistry and cytochemistry. Laboratory Investigation, 57, 5-20.

[8] Danguy A, Kiss R and Pasteels JL. (1988). Lectins in histochemictry: a survey. Biological Structures and Morphogenenesis, 1, 93-106.

[9] Colton CA, Carter A, Patchett J, Keri J and Yao J. (1992). Lectin staining of cultured CNS microglia. The Journal of Histochemistry and Cytochemistry, 40, 505-512.

[10] Gómez-Santos L, Alonso E, Diaz-Flores L, Madrid JF and Sáez FJ. (2017). Characterization by Lectin histochemistry of two subpopulations of parietal cells in the rat gastric glands. Journal of Histochemistry \& Cytochemistry, 65(5), 261-272.

[11] Pang KY, Bresson JL and Walker WA. (1987). Development of gastrointestinal surface VIII. Lectin identification of carbohydrate differences. American Journal of Physiology 252, (Gastrointest. Liver Physiol. 15), G685-G691.

[12] Falk P, Roth KA and Gordon JI. (1994). Lectins are sensitive tools for defining the differentiation programs of mouse gut epithelia. American Journal of Physiology 266 (Gastrointest. Liver Physiology 29), G987-G1003.

[13] Ogunkoya YO and Cook RD. (2009). Histomorphology of the proventriculus of three species Australian passerines: Lichmera indistincta, Zosterops lateralis and Poephila guttata. Anatomia Histologia, Embryologia, 38(4), 246-253.

[14] Ogunkoya YO and Cook RD. (2015). Ultramorphology of the ventriculus of nectarivorous, granivorous and omnivorous species of passerine birds. Nigerian Veterinary Journal, 36(3), 1210 - 1221.

[15] Viale G, Dell'Orto P, Colombi R, De Gennaro V, Comiz A and Coggi G. (1983). Lectin binding sites on semithin sections of epoxy-embedded tissues. In: Bøg-Hansen TC, and Spengler GA, (Eds), Lectins: Biology, Biochemistry, Clinical Biochemistry: Proceedings of the Fifth Lectin Meeting. Walter de Gruyter and Co. Berlin, New York, 3, 199-204.

[16] Cook RD, Flower RLP and Dutton NS. (1983). Light and electron microscopical studies of the immunoperoxidase staining of multiple sclerosis plaques using antisera to a feline- derived agent and to galactocerebroside. Neuropathology and Applied Neurobiology, 12, 63- 79.

[17] Ishuzuya-Oka A and Shimozawa A. (1990). Changes in lectin-binding pattern in the digestive tract of Xenopus laevis during metamorphosis. 1. Gastric region. Journal of Morphology, 205, 1-8.

[18] Brown D, Roth J and Orci L. (1985). Lectin-gold cytochemistry reveals intercalated cell heterogeneity along rat kidney collecting tubules. American Journal of Physiology 248 (Cell Physiol. 17), C348-C356.

[19] Coggi G, Dell'Orto P. Bonoldi E, Doi P and Viale G. (1983). Lectins in diagnostic pathology. In: Bøg-Hansen TC and Spengler GA (Eds) Lectins: Biology, Biochemistry, Clinical Biochemistry: Proceedings of the Fifth Lectin Meeting. Walter de Gruyter and Co. Berlin, New York, 3, 87-103.

[20] Fischer J. (1983). Histochemical and biochemical characterization of glycoprotein components in normal gastric mucosa, intestinal metaplasia and gastric cancers with lectins. In: Bøg-Hansen TC, and Spengler GA, (Eds), 
Lectins: Biology, Biochemistry, Clinical Biochemistry: Proceedings of the Fifth Lectin Meeting. Walter de Gruyter and Co. Berlin, New York, 3, 167-178.

[21] Bloom DW and Fawcett DW. (1975). The oesophagus and stomach. In: A Textbook of Histology, 9th edition, WB Saunders and Co, Philadelphia, 544-559.

[22] Stinson AW and Calhoun ML. (1981). Digestive system. In: Dellman H and Brown EM (Eds), Textbook of Veterinary Histology. Lea \& Febiger. Philadelphia, 232-233.

[23] Toner PG. (1964). The fine structure of the gizzard cells in the domestic fowl. Journal of Anatomy 98, 77-86.

[24] Akester AR. (1986). Structure of the glandular layer and koilin membrane in the gizzard of the adult domestic fowl Gallus gallus domesticus. Journal of Anatomy, 147, 137-151.

[25] Jaeger LA, Lamar CH and Turek JJ. (1987). Lectin binding to small intestinal goblet cells of newborn, suckling, and weaned pigs. American Journal of Veterinary Research, 50, 1984- 1987.

[26] Moré J, Fioramonti J, Bénazet F and Buéno L. (1987). Histochemical characterization of glycoporteins present in jejunal and colonic goblet cells on different diets. Histochemistry, 87, 189-194.

[27] Streit WJ and Kreutzberg GW. (1986). Lectin binding by resting and active microglia. Journal of Neurocytology, $16,249-260$.

[28] Braun PE, Sandillon F, Edwards A, Matthieu JM and Privat A. (1988).Immunocytochemical localization by electron microscopy of 2', 3'-cyclic nucleotide 3'- phosphodiesterase in developing oligodendrocytes of normal and mutant brain. The Journal of Neuroscience, 8, 3057-3066.

[29] Weyer P, Brown D and Orci L. (1988). Lectin-gold labelling of glycoconjugates in normal and brattleboro rat papilla: effect of vasopressin. American Journal of Physiology 254, (Cell Physiol. 23), C450-C458.

[30] Kaur C and Ling EA. (1991). Study of the transformation of amoeboid microglial cells into mircroglia labelled with the isolectin Griffonia simplicifolia in postnatal rats. Acta Anatomica, 141, 118-125.

[31] Ito T, Nagahara N, Ogawa T and Kanisawa, M. (1987). Lectin binding to the luminal surface of bronchiolar neuroepithelial bodies of balb/C mouse. Journal of Electron Microscopy, 36, 26-35.

[32] Pena SD J, Gordon BB, Karpati G and Carpenter S. (1981). Lectin histochemistry of human skeletal muscles. The Journal of Histochemistry and Cytochemistry, 29, 542-546. 